\title{
CAKrawala
}

Management Business Journal [CM:-BJ]] Volume 2 Nomor 2 November Tahun 2019

\section{ANALISIS KESEHATAN BANK DENGAN METODE RISK PROFILE, GOOD CORPORATE GOVERNANCE, EARNING DAN CAPITAL PADA BANK MILIK NEGARA \\ Tahun 2013-2017}

\author{
Skalis Winda Munte ${ }^{1}$, Selmi Dedi ${ }^{2}$, Ted M. Suruan ${ }^{3}$ \\ Universitas Papua
}

Correspondence email: tedsuruan@yahoo.com

\begin{abstract}
ABSTRAK
Penelitian bertujuan untuk menganalisis kesehatan bank dengan menggunakan metode RGEC (Risk Profile, Good Corporate Governance, Earning, dan Capital) Bank Milik Negara 2013-2017.

Jenis masalah penelitian adalah komparatif. Alat analisis yang digunakan di dalam penelitian ini adalah metode RGEC. Risk Profile dinilai menggunakan 3 jenis risiko, yaitu risiko kredit, risiko pasar, dan risiko likuiditas. Good Corporate Governance dinilai menggunakan laporan self assessment bank. Earning dinilai menggunakan, yaitu ROA, ROE, NIM, BOPO. Dan untuk penilaian capital menggunakan rasio CAR.

Hasil penelitian bahwa PT. Bank Rakyat Indonesia (Persero) Tbk memperoleh rata-rata bobot Peringkat Komposit tertinggi, yaitu 94,67\%., PT. Bank Negara Indonesia (Persero) Tbk berada di posisi kedua yaitu $87,11 \%$. dan PT. Bank Tabungan Negara (Persero) Tbk memperoleh rata-rata bobot Peringkat Komposit terendah yaitu 85,78\%. Namun, secara keseluruhan ketiga Bank Milik Negara tersebut masih memperoleh predikat sangat sehat. Namun, diharapkan kepada peneliti selanjutnya, agar dapat mengambil lebih banyak bank untuk memberikan gambaran yang lebih meluas.
\end{abstract}

\begin{abstract}
This research was aimed to analysis risk base bank rating using RGEC (Risk Profile, Good Corporate Governance, Earning, and Capital ) method in Bank of Public Company 2013-2017.

This research was a comparative research. The analyzer was used in this research is RGEC method. Risk Profile was assessed by, credit risk, market risk, and liquidity risk. Good Corporate Governance was assessed by self assessment of bank report. Earning was assessed by, i.e ROA, ROE, NIM, and BOPO. And for capital was assessed by CAR.

The results of the study that PT. Bank Rakyat Indonesia (Persero) Tbk obtains the highest average weighted Composite Rating, which is $94.67 \%$., PT. Bank Negara Indonesia (Persero) Tbk came in second place at $87.11 \%$. and PT. Bank Tabungan Negara (Persero) Tbk obtains the lowest weighted Composite Rating weight of $85.78 \%$. However, overall the three State-Owned Banks are still rated very healthy. However, it is hoped that further researchers will be able to take on more banks to provide a broader picture.
\end{abstract}

Keywords : Risk, Profile, Bank, Rating, RGEC 


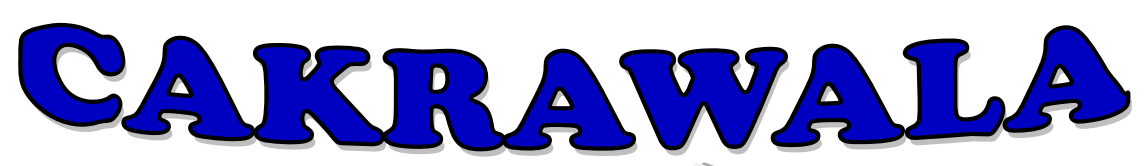

\section{Management Business Journal [CM:B, J] Volume 2 Nomor 2 November Tahun 2019}

\section{PENDAHULUAN}

Peran penting bank dalam kegiatan ekonomi menjadikan lembaga keuangan ini dapat dikatakan sebagai jantung sektor keuangan. Bank dapat berperan dalam menjaga stabilitas sektor keuangan dan stabilitas perekonomian secara makro (Mukhlis, 2015). Keberadaan industri perbankan juga sangat menopang pertumbuhan pengusaha di Indonesia yang berperan sebagai penggerak roda ekonomi negara. Komisaris Independen PT. Bank Mandiri, Tbk, Goei Siauw Hong mengatakan "kalau bank sampai bangkrut yang dirugikan nasabah, seperti saat krisis 1998. Perbankan kolaps berimbas besar ke pengusaha. Mereka tidak bisa mendapat kredit dan akhirnya kegiatan perekonomian tidak bisa berjalan", (Liputan6, 2015). Oleh sebab itu, keberadaan bank bagi suatu negara sangatlah penting.

Bank sebagaimana dimaksudkan dalam Undang-Undang Republik Indonesia No. 10 Tahun 1998 tentang Perubahan atas Undang-Undang Republik Indonesia No. 7 Tahun 1992 tentang Perbankan adalah badan usaha yang menghimpun dana dari masyarakat dalam bentuk simpanan dan menyalurkannya kepada masyarakat dalam bentuk kredit dan atau bentuk-bentuk lainnya dalam rangka meningkatkan taraf hidup rakyat banyak.

Menurut Budisantoso dan Nuritmo (2015), jenis bank dapat dikelompokkan berdasarkan status kepemilikannya menjadi Bank Milik Negara, Bank Milik Swasta Nasional, Bank Milik Swasta Asing, Bank Pembangunan Daerah, dan Bank Campuran. Bank Milik Negara adalah bank yang seluruh modalnya berasal dari kekayaan negara yang dipisahkan dan pendiriannya di bawah undang-undang tersendiri. Artinya, bank milik negara memiliki peran yang lebih besar terhadap pendapatan negara karena merupakan salah satu Badan Usaha Milik Negara (BUMN). Sebagaimana diatur dalam Undang-Undang Nomor 19 tahun 2003 salah satu maksud dan tujuan pendirian BUMN, yaitu memberikan sumbangan bagi perekonomian nasional pada umumnya dan penerimaan negara pada khususnya.

Menurut Ketua Umum Himbara (Himpunan Bank Milik Negara) Gatot Mudiantoro Suwondo pada beritasatu.com, "Bank BUMN memberikan kontribusinya untuk kredit sebesar 40\% terhadap pertumbuhan ekonomi. Kondisi tersebut menggambarkan peran bank pemerintah sebagai agen pembangunan". Berikut adalah data Bank Milik Negara yang ada di Indonesia.

Tabel 1

Daftar Bank Milik Negara di Indonesia

\begin{tabular}{cl}
\hline No. & \\
\hline 1. & PT Bank Mandiri (Persero), Tbk \\
2. & PT Bank Negara Indonesia (Persero), Tbk \\
3. & PT Bank Rakyat Indonesia, Tbk \\
4. & PT Bank Tabungan Negara, Tbk \\
\hline
\end{tabular}

Periode 1997-1999 merupakan masa krisis bagi industri perbankan Indonesia. Krisis moneter yang melanda Indonesia memberikan dampak yang besar bagi perbankan. Krisis perbankan dimulai dengan timbulnya kesulitan likuiditas yang diakibatkan oleh melemahnya 


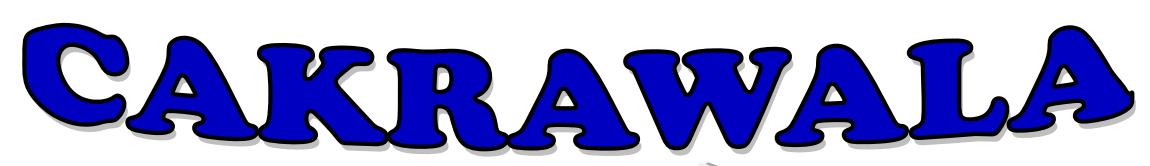

Management Business Journal [CM:-B,] Volume 2 Nomor 2 November Tahun 2019

nilai tukar rupiah yang berakibat pada kesulitan bank dalam memenuhi kewajibannya terhadap luar negeri dan nasabahnya dalam melunasi hutangnya kepada bank (Bank Indonesia, 2006). Krisis perbankan semakin memburuk dengan dicabutnya izin usaha dari 16 bank yang tidak sehat dan tidak solvabel pada 1 November 1997. Pencabutan izin usaha tersebut menyebabkan hilangnya kepercayaan masyarakat terhadap perbankan.

Lembaga Penjamin Simpanan (LPS) mengumumkan daftar bank yang dilikuidasi. Dari 85 bank yang diumumkan 60 bank diantaranya berstatus selesai dilikuidasi, sedangkan 25 bank lainnya masih dalam proses likuidasi (Lembaga Penjamin Simpanan, 2018). Hal ini tentunya dapat memicu kembali hilangnya kepercayaan masyarakat terhadap perbankan seperti yang pernah terjadi sebelumnya pada tahun 1997.

Peraturan Bank Indonesia (PBI) No.13/1/PBI/2011 mengatakan bahwa Kesehatan Bank harus dipelihara dan/atau ditingkatkan agar kepercayaan masyarakat terhadap Bank dapat tetap terjaga. Oleh sebab itu, bank harus terus membangun kepercayaan nasabah dengan menunjukkan bahwa bank dalam kondisi yang sehat dan solvabel untuk bersaing. Melalui penilaian kesehatan bank yang ditetapkan oleh Bank Indonesia dapat menjadi dasar penilaian nasabah terhadap bank.

Kesehatan suatu bank diartikan sebagai kemampuan suatu bank untuk melakukan kegiatan operasional perbankan secara normal dan mampu memenuhi semua kewajibannya dengan baik dengan cara-cara yang sesuai dengan peraturan perbankan yang berlaku (Budisantoso dan Nuritomo, 2015). Sedangkan tingkat kesehatan Bank menurut Peraturan Bank Indonesia (PBI) No.13/1/PBI/2011 Pasal 1 ayat 4 adalah hasil penilaian kondisi Bank yang dilakukan terhadap risiko dan kinerja Bank.

Pada awalnya Bank Indonesia menetapkan penilaian Kesehatan Bank dilakukan dengan menggunakan metode CAMELS seperti yang ditetapkan dalam Peraturan Bank Indonesia Nomor 6/10/PBI/2004 tentang Sistem Penilaian Tingkat Kesehatan Bank Umum. Metode CAMELS terdiri atas capital (permodalan), assets quality (kualitas aset), management (manajemen), earning (rentabilitas), liquidity (likuiditas), dan sensitivity to market risk (sensitivitas terhadap risiko pasar). Metode penilaian ini telah berlaku selama lebih kurang tujuh tahun sejak ditetapkan pada 12 april 2004. Namun, pada tahun 2011 Bank Indonesia mengeluarkan Peraturan Bank Indonesia (PBI) No.13/1/PBI/2011 dengan Surat Edaran No.13/24/DPNP 2011 Romawi III.1.a-III.1.d yang menyatakan bahwa penilaian kesehatan bank tidak lagi menggunakan metode CAMELS melainkan menggunakan metode RGEC. Penilaian kesehatan bank menggunakan metode RGEC terdiri atas risk profile (profil risiko), good corporate goverance (GCG), earning (rentabilitas) dan capital (permodalan).

Berdasarkan latar belakang di atas maka peneliti tertarik untuk meneliti mengenai "Analisis Kesehatan Bank dengan Metode Risk Profile, Good Corporate Governance, Earning dan Capital Pada Bank Milik Negara 2013-2017". 


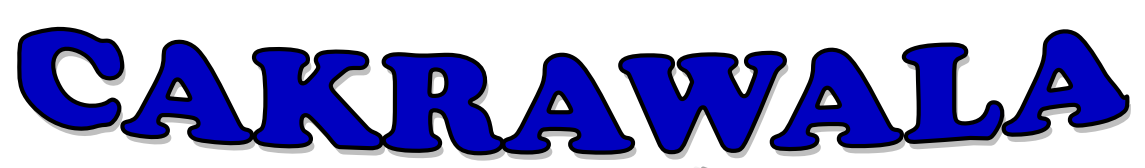

\section{Management Business Journal [CM:B, J] Volume 2 Nomor 2 November Tahun 2019}

\section{METODE PENELITIAN}

Berdasarkan jenis data, penelitian ini adalah penelitian kuantitatif. Sedangkan, berdasarkan tingkat eksplanasinya, penelitian ini adalah penelitian komparatif. Penelitian komparatif adalah suatu penelitian yang bersifat membandingkan (Sugiyono, 1999). Data yang digunakan dalam penelitian ini adalah data sekunder. Data sekunder yang dimaksudkan dalam penelitian ini adalah Laporan Keuangan dan Laporan Self Assessment Bank Milik Negara Periode 2013-2017. Alat analisis yang digunakan dalam penelitian ini adalah analisis RGEC (risk profile, good corporate governance, earnings, dan capital). Risk Profile (Profil Risiko) adalah Penilaian terhadap profil risiko menggunakan 3 (tiga) jenis risiko, yaitu risiko kredit, risiko pasar dan risiko likuiditas dengan rasio-rasio sebagai berikut:

\section{Risiko Kredit}

$\mathrm{NPL}=$ (kredit kurang lancar+kredit diragukan+kredit macet)/(total kredit) $\times 100 \%$

Adapun kriteria penilaian kesehatan bank sesuai standar bank indonesia terlihat pada tabel 1 dibawah ini:

\section{Tabel 1}

Matriks Kriteria Penilaian Kesehatan Bank Pada Risiko Kredit

\begin{tabular}{ccc}
\hline Peringkat & Keterangan & Kriteria \\
\hline 1 & Sangat Sehat & $\mathrm{NPL}<2 \%$ \\
2 & Sehat & $2 \% \leq \mathrm{NPL}<5 \%$ \\
3 & Cukup Sehat & $5 \% \leq \mathrm{NPL}<8 \%$ \\
4 & Kurang Sehat & $8 \% \leq \mathrm{NPL}<12 \%$ \\
5 & Tidak Sehat & $\mathrm{NPL} \geq 12 \%$ \\
\hline
\end{tabular}

Sumber : SEBI No. 13/24/DPNP Tahun 2011

Risiko Pasar

$$
\text { IRR }=\frac{\text { Pendapatan Bunga }}{\text { Beban Bunga }} \times 100 \%
$$

Adapun kriteria penilaian kesehatan bank sesuai standar Bank Indonesia terlihat pada tabel 2 dibawah ini:

Tabel 2

Matriks Kriteria Penilaian Kesehatan Bank Pada Risiko Pasar

\begin{tabular}{ccc}
\hline Peringkat & Keterangan & Kriteria \\
\hline 1 & Sangat Sehat & IRR $>45 \%$ \\
2 & Sehat & $40 \% \leq \mathrm{IRR}<45 \%$ \\
3 & Cukup Sehat & $35 \% \leq \mathrm{IRR}<40 \%$ \\
4 & Kurang Sehat & $30 \% \leq \mathrm{IRR}<35 \%$ \\
5 & Tidak Sehat & $\mathrm{IRR}<30 \%$ \\
\hline
\end{tabular}

Sumber : SEBI No. 13/24/DPNP Tahun 2011 


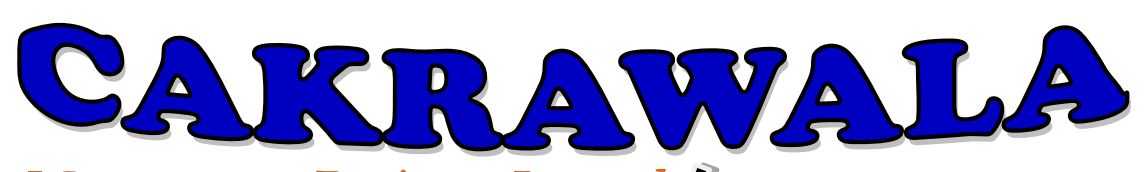

\section{Management Business Journal [CM:-BJ] Volume 2 Nomor 2 November Tahun 2019}

Risiko Likuiditas

$$
\text { LDR }=\frac{\text { Total Kredit }}{\text { Dana Pihak Ketiga }} \times 100 \%
$$

Adapun kriteria penilaian kesehatan bank sesuai standar Bank Indonesia terlihat pada

tabel 3 dibawah ini:

\section{Tabel 3}

Matriks Kriteria Penilaian Kesehatan Bank Pada Risiko Likuiditas

\begin{tabular}{ccc}
\hline Peringkat & Keterangan & Kriteria \\
\hline 1 & Sangat Sehat & LDR $\leq 75 \%$ \\
2 & Sehat & $75 \%<$ LDR $\leq 85 \%$ \\
3 & Cukup Sehat & $85 \%<$ LDR $\leq 100 \%$ \\
4 & Kurang Sehat & $100 \%<$ LDR $\leq 120 \%$ \\
5 & Tidak Sehat & LDR $>120 \%$ \\
\hline
\end{tabular}

Sumber : SEBI No. 13/24/DPNP Tahun 2011

\section{Good Corporate Governance (Tata Kelola Perusahaan)}

Penilaian terhadap Good Corporate Governance akan menggunakan laporan self assessment dari masing-masing bank terlihat pada tabel 4 dibawah ini:

Tabel 4

Matriks Kriteria Penilaian Kesehatan Bank Pada Good Corporate Governance

\begin{tabular}{cc}
\hline Peringkat & Keterangan \\
\hline 1 & Sangat Sehat \\
2 & Sehat \\
3 & Cukup Sehat \\
4 & Kurang Sehat \\
5 & Tidak Sehat \\
\hline
\end{tabular}

Sumber : SEBI No. 13/24/DPNP Tahun 2011

\section{Earning (Rentabilitas)}

Penilaian tehadap earning menggunakan 4 (empat) jenis rasio keuangan, yaitu ROA (return on asset), ROE (return on equity), NIM (net interest margin) dan BOPO (beban operasional pendapatan operasional).

Return on Asset

$$
\text { ROA }=\frac{\text { Laba Sebelum Pajak }}{\text { Rata }- \text { Rata Total Aset }} \times 100 \%
$$




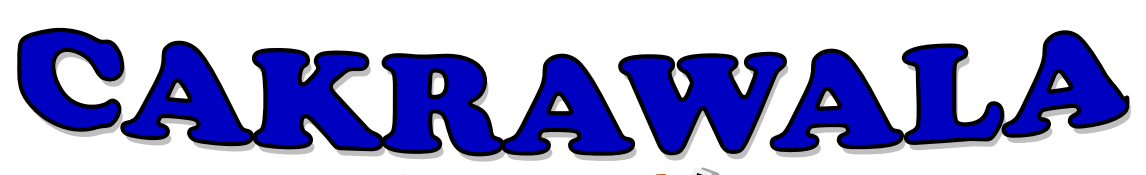

\section{Management Business Journal [CM:B, J] Volume 2 Nomor 2 November Tahun 2019}

Adapun kriteria penilaian kesehatan bank sesuai standar Bank Indonesia terlihat pada tabel 5 dibawah ini:

Tabel 5

Matriks Kriteria Penilaian Kesehatan Bank Rasio Return on Asset (ROA)

\begin{tabular}{ccc}
\hline Peringkat & Keterangan & Kriteria \\
\hline 1 & Sangat Sehat & ROA $>1,5 \%$ \\
2 & Sehat & $1,25 \%<$ ROA $\leq 1,5 \%$ \\
3 & Cukup Sehat & $0,5 \%<$ ROA $\leq 1,25 \%$ \\
4 & Kurang Sehat & $0 \%<$ ROA $\leq 0,5 \%$ \\
5 & Tidak Sehat & ROA $\leq 0 \%$ \\
\hline
\end{tabular}

Sumber : SEBI No. 13/24/DPNP Tahun 2011

Return on Asset

ROA $=($ Laba Sebelum Pajak $) /($ Rata-Rata Total Aset $) \times 100 \%$

Return on Equity

$$
\mathrm{ROE}=\frac{\text { Laba Setelah Pajak }}{\text { Rata }- \text { Rata Total Ekuitas }} \times 100 \%
$$

Adapun kriteria penilaian kesehatan bank sesuai standar Bank Indonesia terlihat pada tabel 6 dibawah ini:

\section{Tabel 6}

Matriks Kriteria Penilaian Kesehatan Bank Rasio Return on Equity (ROE)

\begin{tabular}{ccc}
\hline Peringkat & Keterangan & Kriteria \\
\hline 1 & Sangat Sehat & ROE $>20 \%$ \\
2 & Sehat & $12,5 \%<$ ROE $\leq 20 \%$ \\
3 & Cukup Sehat & $5 \%<$ ROE $\leq 12,5 \%$ \\
4 & Kurang Sehat & $0 \%<$ ROE $\leq 5 \%$ \\
5 & Tidak Sehat & ROE $\leq 0 \%$ \\
\hline
\end{tabular}

Sumber : SEBI No. 13/24/DPNP Tahun 2011

Net Interest Margin

$$
\mathrm{NIM}=\frac{\text { Pendapatan Bunga }}{\text { Rata }- \text { Rata Total Aset Produktif }} \times 100 \%
$$

Adapun kriteria penilaian kesehatan bank sesuai standar Bank Indonesia terlihat pada tabel 7 dibawah ini: 


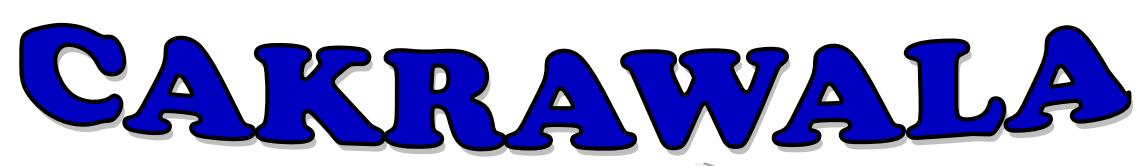

Management Business Journal [CM:B, 2019

Tabel 7

Matriks Kriteria Penilaian Kesehatan Bank Rasio Net Interest Margin (NIM)

\begin{tabular}{ccc}
\hline Peringkat & Keterangan & Kriteria \\
\hline 1 & Sangat Sehat & $\mathrm{NIM}>3 \%$ \\
2 & Sehat & $2 \%<\mathrm{NIM} \leq 3 \%$ \\
3 & Cukup Sehat & $1,5 \%<\mathrm{NIM} \leq 2 \%$ \\
4 & Kurang Sehat & $1 \%<\mathrm{NIM} \leq 1,5 \%$ \\
5 & Tidak Sehat & $\mathrm{NIM} \leq 1 \%$ \\
\hline
\end{tabular}

Page | - 362 -

Sumber : SEBI No. 13/24/DPNP Tahun 2011

Beban Operasional Pendapatan Operasional

$$
\text { BOPO }=\frac{\text { Beban Operasional }}{\text { Pendapatan Operasional }} \times 100 \%
$$

Adapun kriteria penilaian kesehatan bank sesuai standar Bank Indonesia terlihat pada tabel 8 dibawah ini:

Tabel 8

Matriks Kriteria Penilaian Kesehatan Bank Rasio BOPO

\begin{tabular}{ccc}
\hline Peringkat & Keterangan & Kriteria \\
\hline 1 & Sangat Sehat & $\mathrm{BOPO} \leq 83 \%$ \\
2 & Sehat & $83 \%<\mathrm{BOPO} \leq 85 \%$ \\
3 & Cukup Sehat & $85 \%<\mathrm{BOPO} \leq 87 \%$ \\
4 & Kurang Sehat & $87 \%<\mathrm{BOPO} \leq 89 \%$ \\
5 & Tidak Sehat & $\mathrm{BOPO}>89 \%$ \\
\hline
\end{tabular}

Sumber : SEBI No. 13/24/DPNP Tahun 2011

\section{Capital (Permodalan)}

Penilaian terhadap Capital menggunakan rasio kecukupan modal CAR (capital adequency ratio).

$$
\mathrm{CAR}=\frac{\text { Modal }}{\text { Aktiva Tertimbang Menurut Risiko }} \times 100 \%
$$

Adapun kriteria penilaian kesehatan bank sesuai standar Bank Indonesia terlihat pada tabel 9 dibawah ini: 


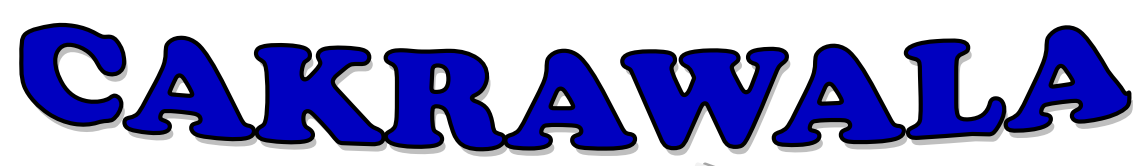

\section{Management Business Journal [CM:B, J] Volume 2 Nomor 2 November Tahun 2019}

Tabel 9

Matriks Kriteria Penilaian Kesehatan Bank Capital Adequency Ratio (CAR)

\begin{tabular}{ccc}
\hline Peringkat & Keterangan & Kriteria \\
\hline 1 & Sangat Sehat & CAR $>12 \%$ \\
2 & Sehat & $9 \% \leq \mathrm{CAR}<12 \%$ \\
3 & Cukup Sehat & $8 \% \leq \mathrm{CAR}<9 \%$ \\
4 & Kurang Sehat & $6 \% \leq \mathrm{CAR}<8 \%$ \\
5 & Tidak Sehat & CAR $\leq 6 \%$ \\
\hline
\end{tabular}

Sumber : SEBI No. 13/24/DPNP Tahun 2011

\section{PERINGKAT KOMPOSIT}

Menurut Paramartha dan Darmayanti, (2017) Setiap hasil perhitungan komponen RGEC akan diberikan pembobotan Peringkat Komposit. Besarnya nilai yang diberikan adalah sebagai berikut:

1. Peringkat Komposit 1 (PK 1) bernilai 5.

2. Peringkat Komposit 2 (PK 2) bernilai 4.

3. Peringkat Komposit 3 (PK 3 ) bernilai 3.

4. Peringkat Komposit 4 (PK 4) bernilai 2.

5. Peringkat Komposit 5 (PK 5) bernilai 1.

Nilai tersebut akan diukur dalam satuan persentase dan akan digunakan untuk menentukan Peringkat Komposit yang akan menentukan tingkat kesehatan bank. Matriks kriteria peringkat komposit penilaian tingkat kesehatan bank disajikan dalam tabel berikut:

Tabel 10

Matriks Kriteria Peringkat Komposit Penilaian Tingkat Kesehatan bank

\begin{tabular}{ccc}
\hline Peringkat Komposit & Keterangan & Kriteria (\%) \\
\hline 1 & Sangat Sehat & $86-100$ \\
2 & Sehat & $71-85$ \\
3 & Cukup Sehat & $61-70$ \\
4 & Kurang Sehat & $41-60$ \\
5 & Tidak Sehat & $<40$ \\
\hline
\end{tabular}

Sumber : Analisis Laporan Keuangan: Penilaian Kesehatan Bank (Setiawan, 2012)

\section{HASIL PENELITIAN}

Adapun hasil penelitian yang diperoleh dari tiga bank yang menjadi objek penelitian adalah sebagai berikut :

\section{Risk Profil BRI}

Adapun hasil risk profil pada bank rakyat indonesia sebagai berikut : 


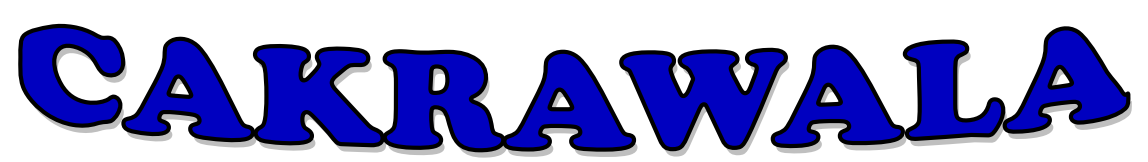

Management Business Journal [CM:-B,] Volume 2 Nomor 2 November Tahun 2019

Tabel 11.

Risk Profile BRI

\begin{tabular}{|c|c|c|c|c|c|c|c|c|c|c|}
\hline \multicolumn{11}{|c|}{ PT. Bank Rakyat Indonesia } \\
\hline & \multicolumn{2}{|l|}{2013} & \multicolumn{2}{|l|}{2014} & \multicolumn{2}{|l|}{2015} & \multicolumn{2}{|l|}{2016} & \multicolumn{2}{|l|}{2017} \\
\hline & $\begin{array}{c}\text { Bobot } \\
\text { (Peringkat) }\end{array}$ & NK & $\begin{array}{c}\text { Bobot } \\
\text { (Peringkat) }\end{array}$ & NK & $\begin{array}{c}\text { Bobot } \\
\text { (Peringkat) }\end{array}$ & NK & $\begin{array}{c}\text { Bobot } \\
\text { (Peringkat) }\end{array}$ & NK & $\begin{array}{c}\text { Bobot } \\
\text { (Peringkat) }\end{array}$ & NK \\
\hline NPL & $1,27 \%(1)$ & 5 & $1,26 \%(1)$ & 5 & $1,17 \%(1)$ & 5 & $1,06 \%(1)$ & 5 & $1,10 \%(1)$ & 5 \\
\hline IRR & $\begin{array}{c}387,25 \% \\
\text { (1) }\end{array}$ & 5 & $317,24 \%(1)$ & 5 & $314,62 \%(1)$ & 5 & $328,92 \%(1)$ & 5 & $360,94 \%(1)$ & 5 \\
\hline LDR & $88,55 \%(3)$ & 3 & $81,75 \%(2)$ & 4 & $86,93 \%(3)$ & 3 & $87,84 \%(3)$ & 3 & $88,18 \%(3)$ & 3 \\
\hline GCG & 1 & 5 & 1 & 5 & 1 & 5 & 2 & 4 & 2 & 4 \\
\hline ROA & $4,74 \%(1)$ & 5 & $4,31 \%(1)$ & 5 & $3,87 \%(1)$ & 5 & $3,61 \%(1)$ & 5 & $3,48 \%(1)$ & 5 \\
\hline ROE & $29,57 \%(1)$ & 5 & $27,33 \%(1)$ & 5 & $24,11 \%(1)$ & 5 & $20,28 \%(1)$ & 5 & $18,49 \%(2)$ & 4 \\
\hline NIM & $8,08 \%$ (1) & 5 & $7,77 \%(1)$ & 5 & $7,53 \%(1)$ & 5 & $7,20 \%$ (1) & 5 & $6,74 \%(1)$ & 5 \\
\hline BOPO & $55,65 \%(1)$ & 5 & $59,69 \%(1)$ & 5 & $58,85 \%(1)$ & 5 & $58,12 \%(1)$ & 5 & $57,04 \%(1)$ & 5 \\
\hline CAR & $22,45 \%(1)$ & 5 & $21,35 \%(1)$ & 5 & $26,49 \%(1)$ & 5 & $28,56 \%$ (1) & 5 & $28,66 \%(1)$ & 5 \\
\hline Total NK & & 43 & & 44 & & 43 & & 42 & & 41 \\
\hline
\end{tabular}

Penilaian terhadap risk profile, yaitu pada risiko kredit untuk tahun 2013-2017 mendapat peringkat 1 dan dikatakan "sangat sehat". Berdasarkan Lampiran Surat Edaran Bank Indonesia Nomor 13/24/DPNP tanggal 25 Oktober 2011, bank dengan perolehan peringkat 1 pada risiko kredit, dinyatakan bahwa kemungkinan kerugian yang dihadapi bank dari risiko kredit tergolong sangat rendah selama periode waktu tertentu di masa datang. Sedangkan untuk kualitas penerapan manajemen Risiko Kredit sangat memadai. Meskipun terdapat kelemahan minor, tetapi kelemahan tersebut tidak signifikan sehingga dapat diabaikan.

Penilaian terhadap risiko pasar PT. Bank Rakyat Indonesia untuk tahun 2013-2017 juga mendapat peringkat 1 dan dikatakan "sangat sehat". Berdasarkan Lampiran Surat Edaran Bank Indonesia Nomor 13/24/DPNP tanggal 25 Oktober 2011, bank dengan perolehan peringkat 1 pada risiko pasar, dinyatakan bahwa kemungkinan kerugian yang dihadapi bank dari risiko pasar tergolong sangat rendah selama periode waktu tertentu di masa datang. Sedangakan untuk kualitas penerapan manajemen Risiko Pasar sangat memadai. Meskipun terdapat kelemahan minor, tetapi kelemahan tersebut tidak signifikan sehingga dapat diabaikan.

Penilaian risiko likuiditas PT. Bank Rakyat Indonesia pada tahun 2013, 2015, 2016 dan 2017 mendapat peringkat 3 dan masih dikatakan "cukup sehat". Berdasarkan Lampiran Surat Edaran Bank Indonesia Nomor 13/24/DPNP tanggal 25 Oktober 2011, dengan mempertimbangkan aktivitas bisnis yang dilakukan bank, kemungkinan kerugian yang dihadapi bank dari Risiko Likuiditas tergolong cukup tinggi selama periode tertentu di masa datang. Dan untuk kualitas manajemen Risiko Likuiditas dikatakan cukup memadai. Meskipun persyaratan minimum terpenuhi terdapat beberapa kelemahan yang membutuhkan perhatian manajemen. Sedangkan untuk tahun 2014 mendapat peringkat 2 dan dinyatakan "sehat", maka dengan 


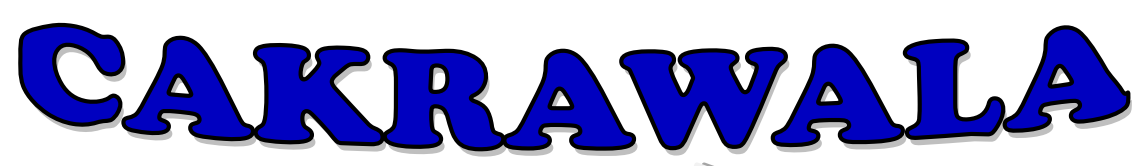

Management Business Journal [CM:-B,] Volume 2 Nomor 2 November Tahun 2019

mempertimbangkan aktivitas bisnis yang dilakukan bank, kemungkinan kerugian yang dihadapi bank dari Risiko Likuiditas tergolong rendah selama periode tertentu di masa datang. Dan untuk penerapan kualitas manajemen Risiko Likuiditas dikatakan memadai. Terdapat beberapa kelemahan minor, tetapi kelemahan tersebut dapat diselesaikan pada aktivitas bisnis normal.

Penilaian terhadap good corporate governance pada PT. Bank Rakyat Indonesia pada tahun 2013-2015 mendapat peringkat 1 dengan predikat "sangat sehat". Hal tersebut mencerminkan manajemen bank telah melakukan penerapan Good Corporate Governance yang secara umum sangat baik. Hal ini tercermin dari pemenuhan yang sangat memadai atas prinsip-prinsip Good Corporate Governance. Apabila terdapat kelemahan, dalam penerapan prinsip Good Corporate Governance, maka secara umum kelemahan tersebut tidak signifikan dan dapat segera dilakukan perbaikan oleh manajemen bank. Sedangkan pada tahun 2016 dan 2017, PT. Bank Rakyat Indonesia mendapat predikat "sehat". Hal tersebut mencerminkan manajemen bank telah melakukan perapanan Good Corporate Governance yang secara umum baik. Hal ini tercermin dari pemenuhan yang memadai atas prinsip-prinsip Good Corporate Governance. Apabila terdapat kelemahan dalam penerapan prinsip Good Corporate Governance, maka secara umum kelemahan tersebut kurang signifikan dan dapat diselesaikan dengan tindakan normal oleh manajemen bank.

Penilaian terhadap rentabilitas (earnings) PT. Bank Rakyat Indonesia berdasarkan rasio return on asset (ROA), return on equity (ROE), net interest margin (NIM) dan beban operasional pendapatan operasional (BOPO) pada tahun 2013-2017 mendapat peringkat 1 dan dikatakan "sangat sehat". Maka, dapat dikatakan bahwa Rentabilitas PT. Bank Rakyat Indonesia sangat memadai, laba melebihi target dan mendukung pertumbuhan permodalan.

Penilaian permodalan (capital) yang menggunakan rasio capital adequency ratio (CAR) PT. Bank Rakyat Indonesia pada tahun 2013-2017 mendapat peringkat 1 dan dikatakan "sangat sehat". Artinya, bank memiliki kualitas dan kecukupan permodalan yang sangat memadai relatif terhadap profil risikonya, yang disertai dengan pengelolaan permodalan yang sangat kuat sesuai dengan karakteristik, skala usaha, dan kompleksitas usaha Bank.

Secara keseluruhan berdasarkan penilaian kesehatan bank PT. Bank Rakyat Indonesia memperoleh Peringkat Komposit 1 atau dikatakan "sangat sehat". Hal ini mencerminkan kondisi PT. Bank Rakyat Indonesia yang secara umum sangat sehat sehingga dinilai sangat mampu menghadapi pengaruh negatif yang signifikan dari perubahan kondisi bisnis dan faktor eksternal lainnya tercermin dari peringkat faktor-faktor penilaian, antara lain profil risiko, penerapan GCG, rentabilitas, dan permodalan yang secara umum sangat baik. Apabila terdapat kelemahan maka secara umum kelemahan tersebut tidak signifikan.

\section{Risk Profil BNI}

Adapun hasil risk profil pada BANK NEGARA INDONESIA sebagai berikut :

Tabel 12

Risk Profile BNI

PT. Bank Negara Indonesia 


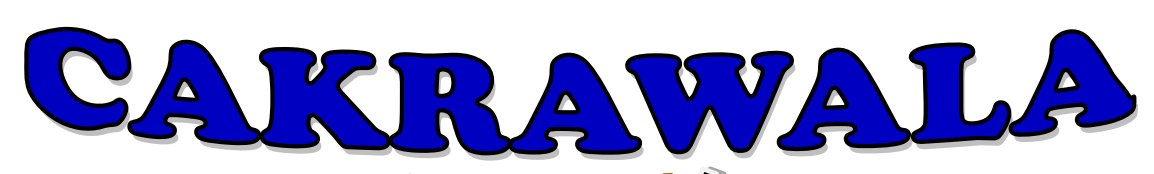

Management Business Journal [CM:-B,] Volume 2 Nomor 2 November Tahun 2019

\begin{tabular}{|c|c|c|c|c|c|c|c|c|c|c|}
\hline & 2013 & & 2014 & & 2015 & & 2016 & & 2017 & \\
\hline & $\begin{array}{c}\text { Bobot } \\
\text { (Peringkat) }\end{array}$ & NK & $\begin{array}{c}\text { Bobot } \\
\text { (Peringkat) }\end{array}$ & NK & $\begin{array}{c}\text { Bobot } \\
\text { (Peringkat) }\end{array}$ & NK & $\begin{array}{c}\text { Bobot } \\
\text { (Peringkat) }\end{array}$ & NK & $\begin{array}{c}\text { Bobot } \\
\text { (Peringkat) }\end{array}$ & NK \\
\hline NPL & $2,16 \%(2)$ & 4 & $1,96 \%(1)$ & 5 & $2,67 \%(2)$ & 4 & $2,96 \%(2)$ & 4 & $2,29 \%(2)$ & 4 \\
\hline IRR & $\begin{array}{c}357,81 \% \\
(1)\end{array}$ & 5 & $307,14 \%(1)$ & 5 & $325,50 \%(1)$ & 5 & $317,78 \%(1)$ & 5 & $247,40 \%$ (1) & 5 \\
\hline LDR & $\begin{array}{c}105,82 \% \\
(4)\end{array}$ & 2 & $108,02 \%(4)$ & 2 & $111,01 \%(4)$ & 2 & $112,21 \%(4)$ & 2 & $105,41 \%$ (4) & 2 \\
\hline GCG & 2 & 4 & 2 & 4 & 2 & 4 & 2 & 4 & 2 & 4 \\
\hline ROA & $3,13 \%(1)$ & 5 & $3,37 \%(1)$ & 5 & $2,48 \%(1)$ & 5 & $2,57 \%(1)$ & 5 & $2,62 \%(1)$ & 5 \\
\hline ROE & $19,86 \%(2)$ & 4 & $19,92 \%(2)$ & 4 & $13,11 \%(2)$ & 4 & $13,61 \%(2)$ & 4 & $14,48 \%(2)$ & 4 \\
\hline NIM & $5,18 \%(1)$ & 5 & $5,95 \%(1)$ & 5 & $5,84 \%(1)$ & 5 & $5,66 \%(1)$ & 5 & $5,00 \%(1)$ & 5 \\
\hline BOPO & $61,20 \%(1)$ & 5 & $60,44 \%(1)$ & 5 & $66,71 \%(1)$ & 5 & $62,78 \%(1)$ & 5 & $63,42 \%(1)$ & 5 \\
\hline CAR & $22,72 \%(1)$ & 5 & $24,76 \%(1)$ & 5 & $24,50 \%(1)$ & 5 & $25,25 \%(1)$ & 5 & $25,20 \%(1)$ & 5 \\
\hline Total NK & & 39 & & 40 & & 39 & & 39 & & 39 \\
\hline
\end{tabular}

Penilaian terhadap risk profile yang dilakukan terhadap risiko kredit, risiko pasar dan risiko likuiditas. Pada risiko kredit untuk tahun 2013, 2015, 2016 dan 2017 mendapat peringkat 2 dan dikatakan "sehat". Hal tersebut menunjukkan kemungkinan kerugian yang dihadapi bank dari risiko kredit tergolong rendah selama perioe waktu tertentu di masa datang. Dan untuk kualitas penerapan manajemen Risiko Kredit memadai. Meskipun terdapat beberapa kelemahan minor, tetapi kelemahan tersebut dapat diselesaikan pada aktivitas bisnis normal. Sedangkan pada tahun 2014 risiko kredit yang diperoleh PT. Bank Negara Indonesia adalah peringkat 1 dengan predikat "sangat sehat". Artinya, kemungkinan kerugian yang dihadapi bank dari risiko kredit tergolong sangat rendah selama periode waktu tertentu di masa datang. Sedangakan untuk kualitas penerapan manajemen Risiko Kredit sangat memadai. Meskipun terdapat kelemahan minor, tetapi kelemahan tersebut tidak signifikan sehingga dapat diabaikan.

Penilaian terhadap risiko pasar PT. Bank Negara Indonesia juga mendapat peringkat 1 dan dikatakan "sangat sehat". Berdasarkan Lampiran Surat Edaran Bank Indonesia Nomor 13/24/DPNP tanggal 25 Oktober 2011, bank dengan perolehan peringkat 1 pada risiko pasar, dinyatakan bahwa kemungkinan kerugian yang dihadapi bank dari risiko pasar tergolong sangat rendah selama periode waktu tertentu di masa datang. Sedangakan untuk kualitas penerapan manajemen Risiko Pasar sangat memadai. Meskipun terdapat kelemahan minor, tetapi kelemahan tersebut tidak signifikan sehingga dapat diabaikan.

Penilaian risiko likuiditas PT. Bank Negara Indonesia pada tahun 2013-2017 mendapat peringkat 4 dan dikatakan "kurang sehat". Berdasarkan Lampiran Surat Edaran Bank Indonesia Nomor 13/24/DPNP tanggal 25 Oktober 2011, dengan mempertimbangkan aktivitas bisnis yang dilakukan bank, kemungkinan kerugian yang dihadapi bank dari Risiko Likuiditas tergolong tinggi selama periode tertentu di masa datang. Dan untuk kualitas manajemen Risiko 


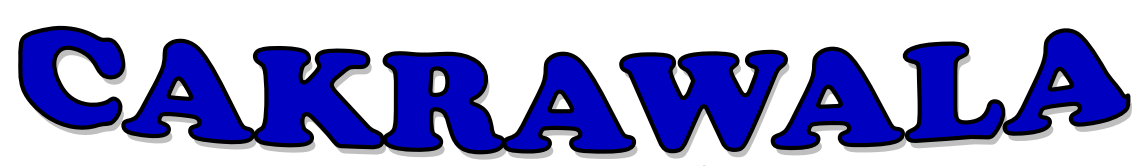

Management Business Journal [CM:-B]] Volume 2 Nomor 2 November Tahun 2019

Likuiditas dikatakan kurang memadai. Terdapat kelemahan signifikan pada berbagai aspek manajemen manajemen Risiko Kredit yang membutuhkan tindakan korektif segera.

Penilaian terhadap Good Corporate Governance pada PT. Bank Negara Indonesia pada tahun 2013-2017 mendapat peringkat 2 dan dikatakan "sehat". Hal ini mencerminkan manajemen bank telah melakukan perapanan Good Corporate Governance yang secara umum baik. Hal ini tercermin dari pemenuhan yang memadai atas prinsip-prinsip Good Corporate Governance. Apabila terdapat kelemahan dalam penerapan prinsip Good Corporate Governance, maka secara umum kelemahan tersebut kurang signifikan dan dapat diselesaikan dengan tindakan normal oleh manajemen bank.

Penilaian terhadap rentabilitas (earnings) PT. Bank Negara Indonesia pada tahun 20132017 berdasarkan rasio return on asset (ROA) mendapat peringkat 1 dan dikatakan "sangat sehat", return on equity (ROE) mendapat peringkat 2 dan dikatakan "sehat", net interest margin (NIM) mendapat peringkat 1 dan dapat dikatakan "sangat sehat" dan beban operasional pendapatan operasional (BOPO) mendapat peringkat 1 dan dikatakan "sangat sehat". Artinya, dapat dikatakan bahwa Rentabilitas PT. Bank Rakyat Indonesia sangat memadai, laba melebihi target dan mendukung pertumbuhan permodalan.

Penilaian permodalan (capital) yang menggunakan rasio capital adequency ratio (CAR) PT. Bank Negara Indonesia pada tahun 2013-2017 mendapat peringkat 1 dan dikatakan "sangat sehat". Artinya, bank memiliki kualitas dan kecukupan permodalan yang sangat memadai relatif terhadap profil risikonya, yang disertai dengan pengelolaan permodalan yang sangat kuat sesuai dengan karakteristik, skala usaha, dan kompleksitas usaha Bank.

Secara keseluruhan berdasarkan penilaian kesehatan bank PT. Bank Negara Indonesia memperoleh Peringkat Komposit 1 atau dikatakan "sangat sehat". Hal ini mencerminkan kondisi PT. Bank Negara Indonesia yang secara umum sangat sehat sehingga dinilai sangat mampu menghadapi pengaruh negatif yang signifikan dari perubahan kondisi bisnis dan faktor eksternal lainnya tercermin dari peringkat faktor-faktor penilaian, antara lain profil risiko, penerapan GCG, rentabilitas, dan permodalan yang secara umum sangat baik. apabila terdapat kelemahan maka secara umum kelemahan tersebut tidak signifikan.

\section{Risk Profil BRI}

Adapun hasil risk profil pada BANK TABUNGAN NEGARA sebagai berikut : Tabel 13

Risk Profile BTN

\begin{tabular}{|c|c|c|c|c|c|c|c|c|c|c|}
\hline \multicolumn{11}{|c|}{ PT. Bank Tabungan Negara } \\
\hline & 2013 & & 2014 & & 2015 & & 2016 & & 2017 & \\
\hline & $\begin{array}{c}\text { Bobot } \\
\text { (Peringkat) }\end{array}$ & NK & $\begin{array}{c}\text { Bobot } \\
\text { (Peringkat) }\end{array}$ & NK & $\begin{array}{c}\text { Bobot } \\
\text { (Peringkat) }\end{array}$ & NK & $\begin{array}{c}\text { Bobot } \\
\text { (Peringkat) }\end{array}$ & NK & $\begin{array}{c}\text { Bobot } \\
\text { (Peringkat) }\end{array}$ & NK \\
\hline NPL & $4,17 \%(2)$ & 4 & $3,90 \%(2)$ & 4 & $3,28 \%(2)$ & 4 & $3,02 \%(2)$ & 4 & $2,83 \%(2)$ & 4 \\
\hline IRR & $210,21 \%$ & 5 & $174,42 \%(1)$ & 5 & $183,52 \%(1)$ & 5 & $190,96 \%(1)$ & 5 & $194,06 \%(1)$ & 5 \\
\hline
\end{tabular}




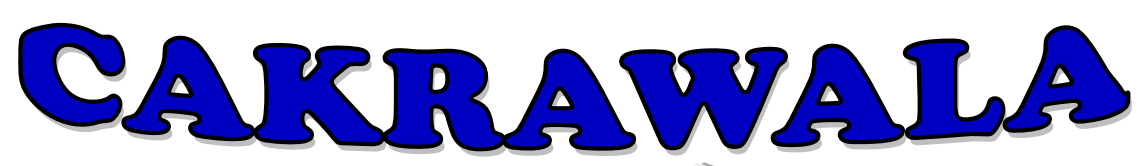

Management Business Journal [CM:-B.J] Volume 2 Nomor 2 November Tahun 2019

\begin{tabular}{|c|c|c|c|c|c|c|c|c|c|c|}
\hline & (1) & & & & & & & & & \\
\hline LDR & $96,03 \%(3)$ & 3 & $99,81 \%(3)$ & 3 & $100,02 \%(4)$ & 2 & $101,65 \%(4)$ & 2 & $102,21 \%(4)$ & 2 \\
\hline GCG & 3 & 3 & 2 & 4 & 2 & 4 & 2 & 4 & 2 & 4 \\
\hline ROA & $1,76 \%(1)$ & 5 & $1,12 \%(3)$ & 3 & $1,60 \%(1)$ & 5 & $1,73 \%(1)$ & 5 & $1,62 \%(1)$ & 5 \\
\hline ROE & $14,28 \%(2)$ & 4 & $9,61 \%(3)$ & 3 & $14,18 \%(2)$ & 4 & $15,88 \%(2)$ & 4 & $14,84 \%(2)$ & 4 \\
\hline NIM & $4,25 \%(1)$ & 5 & $3,78 \%(1)$ & 5 & $4,12 \%(1)$ & 5 & $4,08 \%(1)$ & 5 & $3,89 \%(1)$ & 5 \\
\hline BOPO & $77,76 \%(1)$ & 5 & $82,85 \%(1)$ & 5 & $78,68 \%$ (1) & 5 & $77,96 \%(1)$ & 5 & $77,12 \%(1)$ & 5 \\
\hline CAR & $16,69 \%(1)$ & 5 & $14,54 \%(1)$ & 5 & $15,72 \%(1)$ & 5 & $14,56 \%(1)$ & 5 & $14,45 \%(1)$ & 5 \\
\hline Total NK & & 39 & & 37 & & 39 & & 39 & & 39 \\
\hline
\end{tabular}

Penilaian terhadap risk profile yang dilakukan adalah terhadap risiko kredit, risiko pasar dan risiko likuiditas. Pada risiko kredit untuk tahun 2013-2017 mendapat peringkat 2 dan dikatakan "sehat". Hal tersebut menunjukkan kemungkinan kerugian yang dihadapi bank dari risiko kredit tergolong rendah selama perioe waktu tertentu di masa datang. Dan untuk kualitas penerapan manajemen Risiko Kredit memadai. Meskipun terdapat beberapa kelemahan minor, tetapi kelemahan tersebut dapat diselesaikan pada aktivitas bisnis normal.

Penilaian terhadap risiko pasar PT. Bank Tabungan Negara juga mendapat peringkat 1 dan dikatakan "sangat sehat". Berdasarkan Lampiran Surat Edaran Bank Indonesia Nomor 13/24/DPNP tanggal 25 Oktober 2011, bank dengan perolehan peringkat 1 pada risiko pasar, dinyatakan bahwa kemungkinan kerugian yang dihadapi bank dari risiko pasar tergolong sangat rendah selama periode waktu tertentu di masa datang. Sedangakan untuk kualitas penerapan manajemen Risiko Pasar sangat memadai. Meskipun terdapat kelemahan minor, tetapi kelemahan tersebut tidak signifikan sehingga dapat diabaikan.

Sedangkan penilaian risiko likuiditas PT. Bank Tabungan Negara pada tahun 2013-2014 mendapat peringkat 3 dan dikatakan "cukup sehat". Maka, dengan mempertimbangkan aktivitas bisnis yang dilakukan bank, kemungkinan kerugian yang dihadapi bank dari Risiko Likuiditas tergolong cukup tinggi selama periode tertentu di masa datang. Dan untuk kualitas manajemen Risiko Likuiditas dikatakan cukup memadai. Meskipun persyaratan minimum terpenuhi terdapat beberapa kelemahan yang membutuhkan perhatian manajemen. Sedangkan pada tahun 2015-2017 mendapat peringkat 4 dan dikatakan "kurang sehat". Maka, dengan mempertimbangkan aktivitas bisnis yang dilakukan bank, kemungkinan kerugian yang dihadapi bank dari Risiko Likuiditas tergolong tinggi selama periode tertentu di masa datang. Dan untuk kualitas manajemen Risiko Likuiditas dikatakan kurang memadai. Terdapat kelemahan signifikan pada berbagai aspek manajemen manajemen Risiko Kredit yang membutuhkan tindakan korektif segera.

Penilaian terhadap Good Corporate Governance pada PT. Bank Tabungan Negara pada tahun 2013 mendapat peringkat 3 dan dikatakan "cukup sehat". Hal ini mencerminkan manajemen bank telah melakukan penerapan Good Corporate Governance yang secara umum cukup baik. Hal ini tercermin dari pemenuhan yang cukup memadai atas prinsip-prinsip Good Corporate Governance. Apabila terdapat kelemahan dalam penerapan prinsip Good Corporate Governance, maka secara umum kelemahan tersebut cukup signifikan dan memerlukan perhatian yang cukup dari manajemen bank. Sedangkan pada tahun 2014-2017 mendapat 


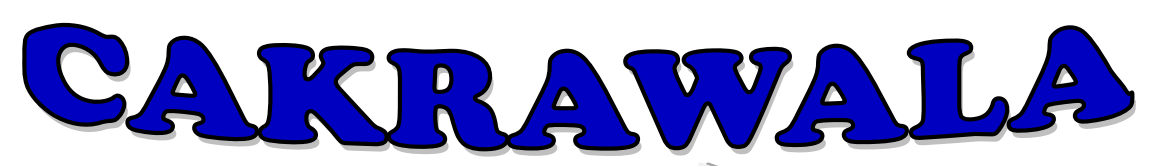

Management Business Journal [CM:-B,] Volume 2 Nomor 2 November Tahun 2019

peringkat 2 dan dapat dikatakan "sehat". Hal ini mencerminkan manajemen bank telah melakukan perapanan Good Corporate Governance yang secara umum baik. Hal ini tercermin dari pemenuhan yang memadai atas prinsip-prinsip Good Corporate Governance. Apabila terdapat kelemahan dalam penerapan prinsip Good Corporate Governance, maka secara umum kelemahan tersebut kurang signifikan dan dapat diselesaikan dengan tindakan normal oleh manajemen bank.

Penilaian terhadap rentabilitas (earnings) PT. Bank Negara Indonesia berdasarkan rasio return on asset (ROA), return on equity (ROE), net interest margin (NIM), beban operasional pendapatan operasional (BOPO) mendapat peringkat 1 dan dikatakan "sangat sehat". Artinya, dapat dikatakan bahwa Rentabilitas PT. Bank Tabungan Negara sangat memadai, laba melebihi target dan mendukung pertumbuhan permodalan.

Penilaian permodalan (capital) yang menggunakan rasio capital adequency ratio (CAR) PT. Bank Tabungan Negara pada tahun 2013-2017 mendapat peringkat 1 dan dikatakan "sangat sehat". Artinya, bank memiliki kualitas dan kecukupan permodalan yang sangat memadai relatif terhadap profil risikonya, yang disertai dengan pengelolaan permodalan yang sangat kuat sesuai dengan karakteristik, skala usaha, dan kompleksitas usaha Bank.

Berdasarkan penilaian kesehatan bank PT. Bank Tabungan Negara secara keseluruhan pada tahun 2013, 2015, 2016 dan 2017 memperoleh Peringkat Komposit 1 atau dikatakan "sangat sehat", hal ini mencerminkan kondisi PT. Bank Tabungan Negara yang secara umum sangat sehat sehingga dinilai sangat mampu menghadapi pengaruh negatif yang signifikan dari perubahan kondisi bisnis dan faktor eksternal lainnya tercermin dari peringkat faktor-faktor penilaian, antara lain profil risiko, penerapan GCG, rentabilitas, dan permodalan yang secara umum sangat baik. Apabila terdapat kelemahan maka secara umum kelemahan tersebut tidak signifikan. Sedangkan pada tahun 2014 PT. Bank Tabungan Negara memperoleh Peringkat Komposit 2 yang dikategorikan "sehat", hal ini mencerminkan kondisi PT. Bank Tabungan Negara yang secara umum sehat sehingga dinilai mampu menghadapi pengaruh negatif yang signifikan dari perubahan kondisi bisnis dan faktor eksternal lainnya tercermin dari peringkat faktor-faktor penilaian, antara lain profil risiko, penerapan GCG, rentabilitas, dan permodalan yang secara umum baik. Apabila terdapat kelemahan maka secara umum kelemahan tersebut kurang signifikan.

\section{PEMBAHASAN}

\section{Perbandingan Analisis Kesehatan Bank dari Ketiga Bank Milik Negara}

Berdasarkan tabel 14 dapat dilihat perolehan bobot Peringkat Komposit (PK) yang diperoleh ketiga Bank Milik Negara, dengan rata-rata bobot PK tertinggi diperoleh Bank Rakyat Indonesia. Dari tabel tersebut dapat dilihat bahwa dari tahun 2013-2017 Bank Rakyat Indonesia memperoleh bobot PK $>90 \%$. Hal ini tercermin dari penilaian tehadap faktor-faktor risk profile, good corporate governance, earnings,dan capital yang telah dilakukan terhadap Bank Rakyat Indonesia, bahwa pada tahun 2013-2017 dapat dilihat pada tabel 4.28 Bank Rakyat Indonesia secara keseluruhan memperoleh peringkat 1 dengan predikat "sangat sehat". 


\section{CAKrawala}

Management Business Journal [C,M]-B]J] Volume 2 Nomor 2 November Tahun 2019

Tabel 14

Penilaian Peringkat Komposit Tingkat Kesehatan Bank

\begin{tabular}{cccccc}
\hline & Tahun & $\begin{array}{c}\text { Nilai } \\
\text { Komposit } \\
\text { NK) }\end{array}$ & Bobot PK & $\begin{array}{c}\text { Peringkat } \\
\text { Komposit } \\
\text { (PK) }\end{array}$ & Keterangan \\
\hline PT. Bank Rakyat & 2013 & 43 & $95,56 \%$ & 1 & Sangat Sehat \\
Indonesia & 2014 & 44 & $97,78 \%$ & 1 & Sangat Sehat \\
& 2015 & 43 & $95,56 \%$ & 1 & Sangat Sehat \\
& 2016 & 42 & $93,33 \%$ & 1 & Sangat Sehat \\
& 2017 & 41 & $91,11 \%$ & 1 & Sangat Sehat \\
\hline PT. Bank Negara & 2013 & 39 & $86,67 \%$ & 1 & Sangat Sehat \\
Indonesia & 2014 & 40 & $88,89 \%$ & 1 & Sangat Sehat \\
& 2015 & 39 & $86,67 \%$ & 1 & Sangat Sehat \\
& 2016 & 39 & $86,67 \%$ & 1 & Sangat Sehat \\
& 2017 & 39 & $86,67 \%$ & 1 & Sangat Sehat \\
\hline PT. Bank & 2013 & 39 & $86,67 \%$ & 1 & Sangat Sehat \\
Tabungan Negara & 2014 & 37 & $82,22 \%$ & 2 & Sehat \\
& 2015 & 39 & $86,67 \%$ & 1 & Sangat Sehat \\
& 2016 & 39 & $86,67 \%$ & 1 & Sangat Sehat \\
& 2017 & 39 & $86,67 \%$ & 1 & Sangat Sehat \\
\hline
\end{tabular}

Kemudian di posisi kedua diperoleh oleh Bank Negara Indonesia dan posisi ketiga diperoleh oleh Bank Tabungan Negara. Perolehan bobot PK Bank Negara Indonesia dan Bank Tabungan Negara pada tahun 2013, 2015, 2016, dan 2017 yaitu 86,67\%, yang membedakan adalah perolehan bobot PK pada tahun 2015 dimana Bank Negara Indonesia memperoleh $88,89 \%$ sedangkan Bank Tabungan Negara memperoleh $82,22 \%$. Hal inilah yang menyebabkan Bank Negara Indonesia berada di posisi kedua sedangkan Bank Tabungan Negara di posisi ketiga.

Berdasarkan tabel 12 dan tabel 13 dapat dilihat perbandingan perolehan nilai komposit dari Bank Negara Indonesia dan Bank Tabungan Negara. Pada tahun 2014 untuk penilaian risk profile pada risiko kredit Bank Negara Indonesia memperoleh peringkat 1 dengan persentase 1,96\%, sedangkan Bank Tabungan Negara memperoleh peringkat 2 dengan persentase 3,90\%. Dan untuk penilaian pada risiko likuiditas Bank Tabungan Negara lebih unggul dengan memperoleh peringkat 3 sedangkan Bank Negara Indonesia memperoleh peringkat 4 dengan masing-masing persentase perolehan $99,81 \%$ dan $108,02 \%$. Sedangkan untuk penilaian earning pada rasio return on asset (ROA) dan return on equity (ROE) Bank Negara Indonesia unggul dengan peringkat 1 (3,37\%) untuk ROA dan peringkat 2 (19,92\%) untuk ROE dan Bank Tabungan Negara memperoleh peringkat $3(1,12 \%)$ untuk ROA dan peringkat $3(9,61 \%)$ untuk ROE. 


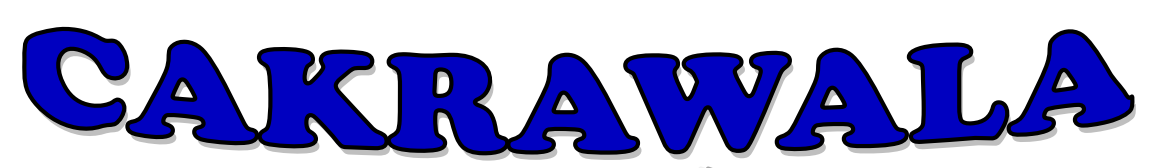

\section{Management Business Journal [CM:B, J] Volume 2 Nomor 2 November Tahun 2019}

\section{KESIMPULAN}

Berdasarkan penilaian tingkat kesehatan bank pada ketiga Bank Milik Negara selama periode 2013-2017, maka dapat disimpulkan bahwa PT. Bank Rakyat Indonesia memperoleh persentase bobot Peringkat Komposit tertinggi, yaitu pada tahun 2014 sebesar 97,78\% dan yang terendah pada tahun 2017 dengan persentase bobot Peringkat Komposit sebesar 91,11\%. Kemudian PT. Bank Negara Indonesia berada di posisi kedua dengan perolehan persentase bobot Peringkat Komposit tertingggi pada tahun 2014 sebesar 88,89\% dan pada tahun 2013, 2015, 2016 dan 2017 memperoleh bobot Peringkat Komposit yang sama yaitu sebesar 86,67\%. Dan yang terakhir adalah PT. Bank Tabungan Negara dengan perolehan bobot Peringkat Komposit tertinggi pada tahun 2013, 2015, 2016 dan 2017 yaitu sebesar 86,67\% dan terendah pada tahun 2014 sebesar $82,22 \%$.

\section{REKOMENDASI}

Adapun saran yang dapat diberikan bahwa profile risk dari sample penelitian terlihat sangat sehat, namun terbatas pada tiga bank. Sehingga belum bisa menggambarkan keseluruhan bank yang ada. Untuk itu diharapkan kepada peneliti selanjutnya, agar dapat mengambil lebih banyak bank dan menggunakan aplikasi berhitung seperti Microsoft Excel untuk mempermudah perhitungan data.

\section{DAFTAR REFERENSI}

Ariyanti, F. 2015. Ini Penyebab Perbankan Bisa Bangkrut. Jakarta: https://www.liputan6.com/bisnis/read/2314978/ini-penyebab-perbankan-bisabangkrut. [30 April 2018]

Bank Indonesia. 2011. Peraturan Bank Indonesia (PBI) No. 13/1/PBI/2011 Pasal 1 Ayat 4 tentang Penilaian Tingkat Kesehatan Bank Umum. Gubernur Bank Indonesia. Jakarta.

Bank Indonesia. 2011. Surat Edaran No.13/24/DPNP 2011 tentang Penilaian Tingkat Kesehatan Bank Umum. Gubernur Bank Indonesia. Jakarta.

Budisantoso, T., \& Nuritomo. 2015. Bank dan Lembaga Keuangan Lain Edisi 3. Jakarta: Salemba Empat.

GRC. 2013. Kontribusi Bank BUMN Capai 35\% Di Perbankan. Jakarta: beritasatu.com.

Lembaga Penjamin Simpanan. 2018. Bank Yang Dilikuidasi. Dipetik 04 03, 2018, dari Lembaga Penjamin Simpanan: http://www.lps.go.id/bank-yang-dilikuidasi.

Mukhlis, I. 2015. Ekonomi Keuangan \& Perbankan. Jakarta: SAlemba Empat.

Paramartha, I., \& Darmayanti, N. A. 2017. Penilaian Tingkat Kesehatan Bank dengan Metode RGEC pada PT. Bank Mandiri (Persero), Tbk. E-Jurnal Manajemen Unud, Vol. 6, No. 2.

Republik Indonesia. 1998. Undang-Undang Republik Indonesia No. 10 Tahun 1998 tentang Perubahan atas Undang-Undang Republik Indonesia No. 7 Tahun 1992 tentang Perbankan. Sekretariat Negara. Jakarta.

Republik Indonesia. 2003. Undang-Undang Republik Indonesia N0. 19 Tahun 2003 tentang Badan Usaha Milik Negara. Sekretariat Negara. Jakarta. 